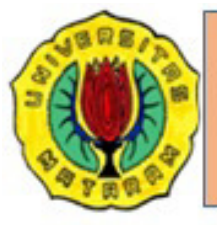

\title{
Studi eksperimental terhadap porositas dan hambat alir udara pada komposit penyerap suara
}

\author{
N.H. Sari, J. Fajrin, I.G.N.K. Yudhyadi
}

Teknik Mesin Fakultas Teknik Universitas Mataram, Jln. Majapahit No. 62 Mataram Nusa Tenggara Barat, 83125, Telp. (0370) 636087; 636126; ext 128 Fax (0370) 636087.

*Email: n.herlinasari@unram.ac.id

\section{ARTICLE INFO}

Article History:

Received 30 September 2017

Accepted 9 October 2017

Available online 1 January 2018

\section{Keywords:}

Air flow resistivity

Composite

Fibrous

Porosity

Sound absorber

\section{ABSTRACT}

In this paper, we present a comprehensive analytical and experimental investigation for the determination of the air flow resistivity and porosity of sound absorber composite. The ratio of the volume fraction of fiber and polyester resin is 15, 25, 35, 55 and 65 (\%). The dimensions of the absorbent composite sample are $29 \mathrm{~mm} \times 20 \mathrm{~cm}$ (diameter $x$ thickness). Porosity and Air flow resistivity of composites have been investigated. The results showed that the porosity of the composites increased with increasing amount of fiber due to the interface between fiber and resinless dense. In contrast, the air flow resistivity values are lower with a denser resin and fiber interface.

\section{PENDAHULUAN}

Meskipun bahan komposit berserat dan komposit polimer telah banyak digunakan untuk aplikasi pengendalian kebisingan, ada peningkatan minat untuk terus mengembangkan dan menyelidiki potensi dari komposit penyerap dari serat alam, contoh komposit penyerap dari serat kulit jagung, untuk aplikasi interior otomotif; menyerap suara yang ditimbulkan oleh angin, mesin, ban dan percakapan (Sari et al., 2017).

Parameter hambat alir udara dan porositas bahan penyerap merupakan faktor yang paling penting untuk penyerapan suara dan akibatnya terhadap disipasi energi gelombang suara dalam pori-pori (Sari et al., 2017). Beberapa peneliti telah mengembangkan metode untuk menentukan kedua parameter tersebut. Umnova et al. (2005) telah menginvestigasi tortuositas, and porositas dari ketebalan spesimen bahan berpori kaku. Menggunakan metode pulsa dengan frekuensi pusat mendekati $12 \mathrm{kHz}$ dan perkiraan bandwidth antara 3 dan $20 \mathrm{kHz}$. Mereka melaporkan bahwa tortuositas diperoleh dari batas frekuensi tinggi kecepatan fase dan porositas diperoleh dari batas frekuensi tinggi koefisien refleksi setelah tortuositas diketahui. Allard et al. (1994) mempelajari tortuositas dalam bahan berpori jenuh udara. Mereka melaporkan bahwa tortuositas spesimen berpori udara jenuh dapat diperoleh dari pengukuran kecepatan gelombang pada frekuensi ultrasonik menggunakan time-of-flight pulsa akustik yang melalui sampel selama tidak ada pelemahan signifikan dan dispersi. Zacarias et al. (2005) telah menggunakan finite difference dan skema numerik boundary element untuk memprediksi streamlines dalam biofilm. Mereka 
melaporkan bahwa nilai dari porositas dan tortuositas biofilm dapat dihitung dan dibandingkan dengan mengasumsikan bahwa biofilm terendam dalam fluida dengan memberikan viskositas dan nilai Reynold rendah. Selanjutnya, Sari et al. (2017) juga telah menyelidiki sifat non akustik dan akustik dari komposit CHF - poliester. Mereka melaporkan bahwa fraksi volume CHF $80 \%$ dalam resin poliester memiliki nilai porositas sekitar $0.7954 \%$ dan hambat alir udara 14,435 (Pa.s $\left./ \mathrm{m}^{2}\right)$ yang menyebabkan koefesien penyerapan suara komposit dapat diperoleh sebesar 0.94. Studistudi sebelumnya ini menyampaikan bahwa pemahaman yang lebih baik pada parameter porositas dan hambat alir udara pada bahan penyerap dapat membantu dalam mengembangkan bahan akustik performansi tinggi.

Oleh sebab itu, dalam paper ini kami menyajikan pemahaman dan analisa eksperimental terkait dengan parameter hambat alir udara dan porositas komposit CHF. Pemahaman secara eksperimental ini merupakan upaya kami untuk menentukan porositas dan tortuositas dalam bahan komposit penyerap suara berbahan corn husk fiber dan matrik poliester.

\section{METODE PENELITIAN}

Corn husk fiber telah diekstraksi dari limbah corn husk menggunakan metode water retting selama 14 hari untuk mengalami proses degradasi micro-bacterial. Berikutnya, serat diberikan perlakuan alkali $\mathrm{NaOH} 5 \%$. Mereka dibilas dan dicuci bersih menggunakan air biasa dan dikeringkan dengan cara diangin-anginkan yang selanjutnya siap digabung dengan matrik resin. Perlakuan alkali dimaksudkan untuk meningkatkan kekuatan dan kualitas ikatan antara serat dan resin (Sari et al., 2017). Diameter rata-rata dari CHF tunggal yaitu $0.133 \pm 0.03 \mathrm{~mm}$ (telah diukur menggunakan Mitutoyo digital micrometer).

Matrik resin yang digunakan adalah poliester tipe 2250 BW-EX memiliki kekuatan tarik sebesar $8.8 \mathrm{Kg} / \mathrm{mm}^{2}$, modulus tarik sebesar 500 $\mathrm{Kg} / \mathrm{mm}^{2}$, dan elongasi sebesar $2.3 \%$.

Dalam pembuatan spesimen: CHF dan poliester diukur dalam prosentasi fraksi volume. Rasio bahan baku komposit diperlihatkan dalam Tabel 1.

Tabel 1. Rasio dari serat dan poliester dalam komposit penyerap (\% fraksi volume).

\begin{tabular}{llllll}
\hline $\begin{array}{c}\text { Kode } \\
\text { spesimen }\end{array}$ & NA & NS & NH & SH & SN \\
\hline CHFs & 15 & 25 & 35 & 55 & 65 \\
Polyester & 85 & 75 & 65 & 45 & 35 \\
\hline
\end{tabular}

Campuran dibentuk dengan teknik hot press pada temperatur $105^{\circ} \mathrm{C}$ dan $0.3 \mathrm{MPa}$ selama 4 menit dalam cetakan melingkar, yang diikuti dengan pendinginan dalam temperatur ruangan pada $5 \mathrm{MPa}$. Spesimen memiliki ukuran diameter $29 \mathrm{~mm}$ dan ketebalan $20 \mathrm{~mm}$. Lima jenis spesimen dihasilkan untuk uji porositas.

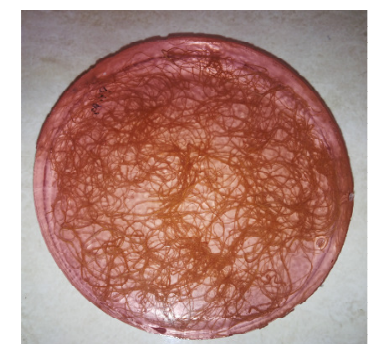

(a)

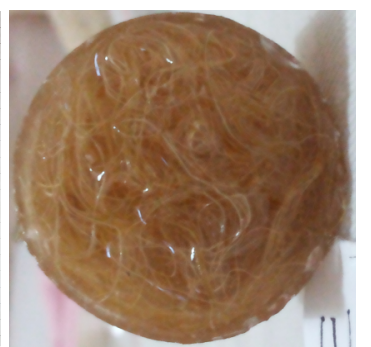

(b)
Gambar 1. Spesimen uji porositas a. Fraksi volume serat $15 \%$ (Kode NA), dan b. Fraksi volume serat $65 \%$ (Kode SN).

\section{Karakterisasi spesimen komposit Porositas}

Porositas terhubung dari komposit penyerap diukur secara non-akustik dengan menggunakan metode saturasi air yang digunakan oleh Vasina et al. (2006) dan Sari et al. (2017). Semua spesimen komposit dikeringkan dengan menggunakan Oven pada temperatur $105{ }^{\circ} \mathrm{C}$ selama 24 jam. Selanjutnya, mereka ditimbang sebelum diletakkan dalam sebuah vacuum vessel untuk penjenuhan dibawah air; dimana densitas air diketahui sebesar, $\rho_{w}=1000 \mathrm{Kg} / \mathrm{m}^{3}$. Setelah 24 jam, mereka dengan hati-hati diangkat dan ditimbang lagi. Porositas dihitung menggunakan $\varepsilon=V_{\mathrm{c}} / V_{\mathrm{s}}$, dengan $V_{c}$ yaitu volume spesimen komposit yang dihuni oleh air dan $V_{s}$ yaitu total volume dari spesimen komposit. Volume air dapat ditentukan menggunakan, $V_{w}=\left(m_{1}-m_{0}\right) / \rho_{w}$, dengan $m_{1}$ yaitu massa basah dari spesimen komposit $(\mathrm{Kg})$, dan $m_{0}$ yaitu massa kering dari spesimen komposit $(\mathrm{Kg})$. Foto proses pengukuran porositas diperlihatkan dalam Gambar 2.

\section{Hambat alir udara}

Nilai hambat alir udara spesimen komposit diukur dengan mempertimbangkan radius serat (a), densitas dan porositas spesimen $(\varepsilon)$, seperti dituliskan dalam persamaan 1 (Mechel, 2008); (Maderuelo-Sanz et al., 2012):

$$
R=\frac{6.8 \mu(1-\varepsilon)}{a^{2} \varepsilon^{3}},
$$


$\mu$ adalah viskositas udara $\left(1.84 \times 10^{-5}\right.$ Pa.s $)$.

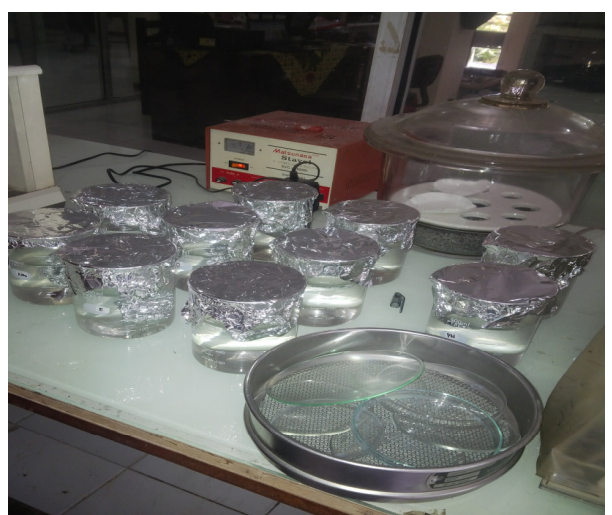

Gambar 2. Foto proses pengukuran porositas spesimen komposit

\section{HASIL DAN PEMBAHASAN}

\section{Analisa porositas,}

Hasil experimental porositas dari komposit CHF - Poliester diperlihatkan dalam Gambar 3.

Gambar 3 menunjukkan bahwa nilai porositas terbesar komposit sampel yaitu 0.758 , dimiliki oleh sampel SN dengan rasio serat dan resin poliester yaitu 65:35 (\% fraksi volume) daripada sampel komposit $\mathrm{SH}, \mathrm{NH}$, NS, dan NA. Nilai porositas terendah dimiliki oleh sampel NA dengan nilai rata-rata 0.572 . Penambahan jumlah resin yang lebih besar dalam komposit menyebabkan struktur atau interface yang lebih rapat antara serat dan resin, sehingga nilai porositasnya lebih rendah. Sebaliknya, nilai porositas tinggi; karena interface antara serat dan resin kurang rapat dengan jumlah serat meningkat. Dengan kata lain, jumlah resin yang sedikit tidak mampu membasahi semua serat, sehingga porositas komposit menjadi tinggi. Selain itu, keberadaan lumen dalam bundel serat tunggal juga meningkatkan porositas dalam komposit. Sari et al. (2017) melaporkan bahwa struktur serat yang multiscale dengan adanya lumen di dalam bundel serat memiliki bentuk poripori dan ukuran pori-pori yang dapat berbeda arah. Lumen dalam bundel serat tunggal diperlihatkan dalam Gambar 4.

Diameter CHF telah diukur dengan Mitutoyo digital micrometer, dengan keakuratan 0.0001 . Rata-rata diameter tunggal CHF sebesar $0.133 \pm$ $0.03 \mathrm{~mm}\left(\rho=560 \mathrm{~kg} / \mathrm{m}^{3}\right)$. Crocker dan Arenas (2007) melaporkan bahwa bahan berpori biasanya memiliki koefisien penyerapan suara tinggi. Bahan yang mengandung atau memiliki rongga, saluransaluran atau celah menyebabkan gelombang suara mampu masuk melalui mereka (Rouquerol et al., 1994). Dengan pori-pori tersebut energi suara yang diterima akan diubah menjadi energi termal karena bergesekan dengan molekul udara.

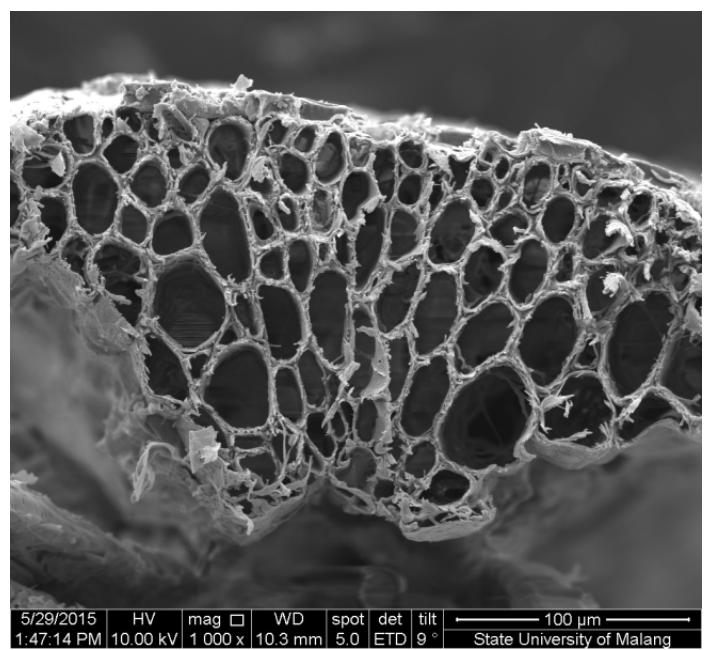

Gambar 4. Lumen dalam bundel serat Corn husk fiber (Sari et al., 2017).

\section{Analisa hambat alir udara}

Berdasarkan hasil pengukuran yang telah diperoleh, seperti ditunjukkan dalam gambar 5 telah diketahui bahwa nilai hambat alir udara $(R)$ tertinggi dimiliki oleh sampel NA yaitu 77732 $\mathrm{Pa} . \mathrm{s} / \mathrm{m}^{2}$ dengan rasio serat dan resin poliester yaitu 15:85 (\% fraksi volume) daripada sampel komposit $\mathrm{NH}$, NS, SH, dan SN. Nilai hambat alir terendah dimiliki oleh sampel NA sebesar 19551 $\mathrm{Pa} . \mathrm{s} / \mathrm{m}^{2}$ dengan fraksi volume serat $80 \%$. Peningkatan jumlah resin poliester diindikasi telah menyebabkan resistensi aliran udara bahan semakin tinggi karena interface yang lebih rapat antara serat dan resin. Sebaliknya nilai resistensi aliran udara rendah karena jumlah serat meningkat.

Lebih lanjut, Seddeq (2009) menyatakan bahwa hambatan aliran udara yang lebih tinggi memiliki nilai penyerapan suara kurang dari 1000 karena sulitnya gerakan gelombang suara yang melalui bahan. 


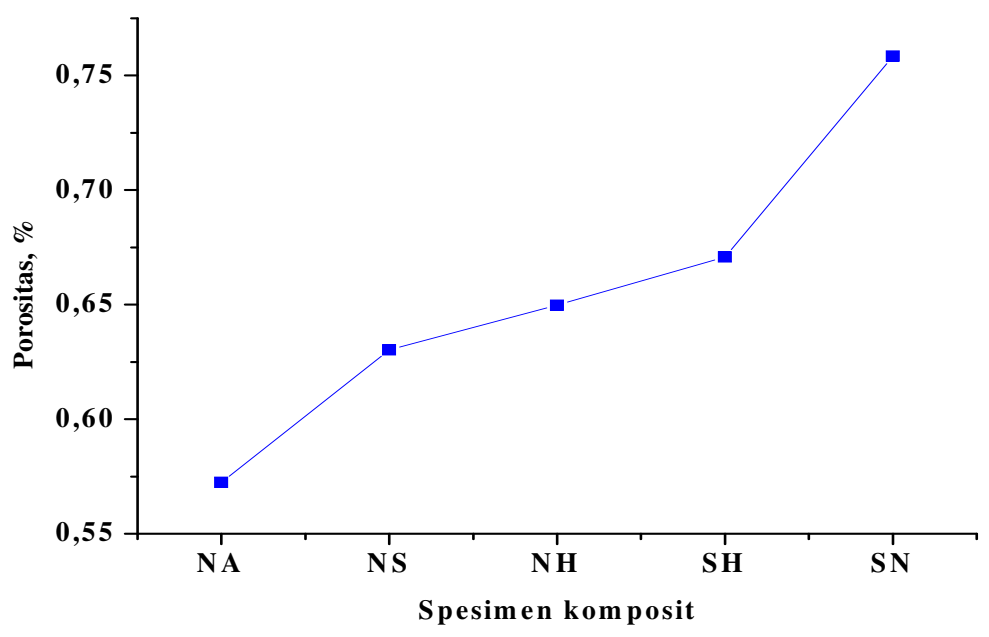

Gambar 3. Porositas dari komposit CHF - Poliester pada sampel berbeda

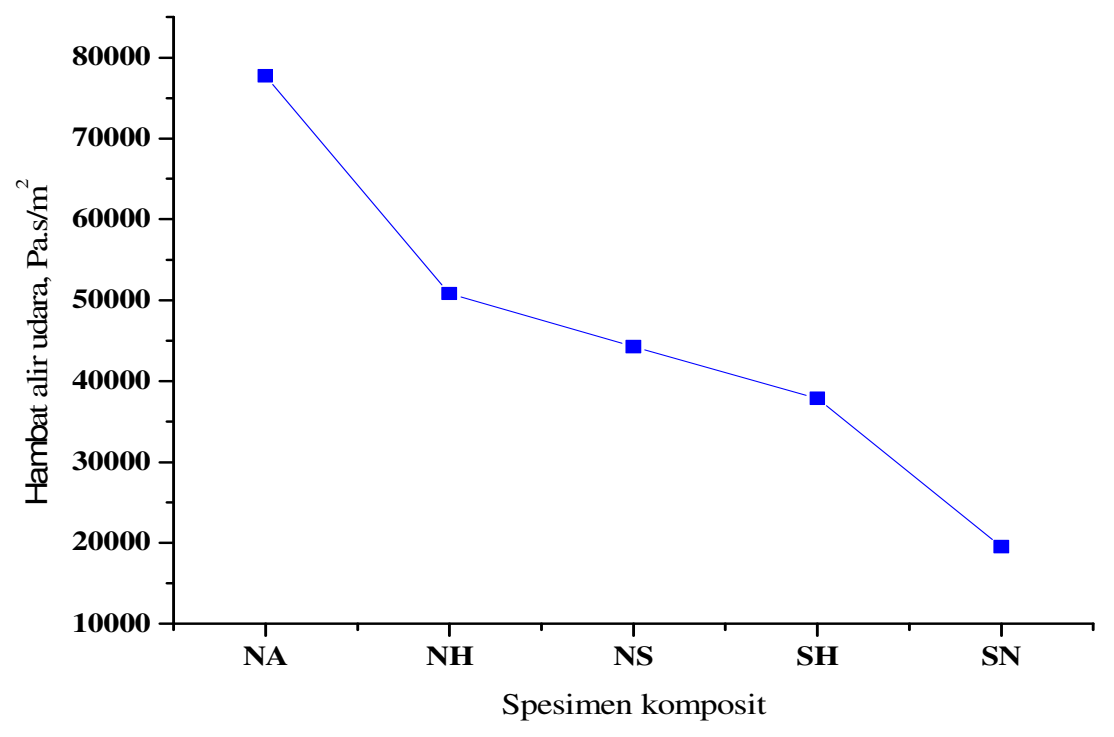

Gambar 5. Hambat alir udara dari komposit CHF- Poliester pada sampel berbeda.

\section{KESIMPULAN}

Berdasarakan hasil eksperimental dapat disimpulkan bahwa penambahan fraksi volume serat dalam komposit meningkatkan nilai porositas dari komposit karena interface antara serat-resin semakin kurang rapat. Sebaliknya,nilai hambat alir udara dari bahan menurun dengan bertambahnya serat corn husk.

\section{DAFTAR PUSTAKA}

Allard J.F., Castagnede B., Henry M., Lauriks W., 1994, Evaluation of tortuosity in acoustic porous materials saturated by air, Rev Sci Instrum, 65, 754-5.

Crocker M.J., Arenas J.P., 2007, Use of soundabsorbing materials, Chapter 57 in Handbook of Noise and Vibration Control 
(M.J. Crocker, Ed.), John Wiley and Sons, New York.

Mechel F.P., 2008, Formulas of acoustics, 2nd edition, Springer, Germany.

Maderuelo-Sanz R., Nadal-Sisbert A.V., Crespoamorós J.E., Farres-Garcia F., 2012, A novel sound absorber with recycled fibers coming from the end of life tires (ELTs), Applied Acoustics, 73(4), 402-408.

Sari N.H., Wardana I.N.G., Irawan Y.S., Siswanto E., 2017, Corn husk fiber-polyester composites as sound absorber: nonacoustical and acoustical properties, Advances in Acoustics and Vibration.

Sari N.H., Wardana I.N.G., Irawan Y.S., Siswanto E., 2017, characterization of the chemical, physical, and mechanical properties of $\mathrm{NaOH}$-treated natural cellulosic fibers from corn husks, Journal of Natural Fibers.

Seddeq H.S., 2009, Factors Influencing Acoustic Performance of Sound Absorptive Materials, Australian Journal of Basic and Applied Sciences, 3(4), 4610-4617.

Umnova O., Attenborough K., Chul-Shin H., Cummings A., 2005, Deduction of tortuosity and porosity from acoustic reflection and transmission measurements on thick samples of rigid-porous materials, Applied Acoustics, 66, 607-624.

Vašina M., Hughes D.C., Horoshenkov K.V., Lapcık Jr.L., 2006, The acoustical properties of consolidated expanded clay granulates, Applied Acoustics, 67, 787-796. 